\title{
PRANAYAMA YOGA AND MUSIC THERAPY: A HOLISTIC REHABILITATION THERAPY COMBINATION FOR CHRONIC OBSTRUCTIVE PULMONARY DISEASE PATIENT
}

\author{
I Putu Hendri Aryadi, I Gusti Agung Ayu Andra Yusari, Haikal Hamas Putra Iqra \\ Faculty of Medicine, Udayana University, Jl. P.B. Sudirman, Postal Code 80232, Denpasar, Bali, Indonesia
}

\begin{abstract}
The management of certain health disorder can be done through a combination of conventional methods, namely with medicine, as well as traditional in a holistic (comprehensive) manner. The same also can be done for people with chronic obstructive pulmonary disease (COPD). Breath training technique and selfrelaxation can be used as a complement, in addition to the consumption of drugs. Yoga pranayama combined with music therapy is a new rehabilitation therapy combination that can be implemented. This study was a narrative literature review composed by original articles and reviews written in English, aims to determine the potential of a combination of yoga pranayama and music therapy as a holistic rehabilitation therapy in patients with COPD. That therapy combination has been proven capable by some literatures in reducing dyspnea, increasing lung capacity and oxygen saturation, improving fitness and minimizing anxiety level, however, there were not any studies that ensure the potency of this therapy combination in COPD patients, therefore further research should be addressed.
\end{abstract}

Keywords: Pranayama yoga, music therapy, rehabilitation, holistic

\begin{abstract}
ABSTRAK
Tata laksana suatu gangguan kesehatan dapat dilakukan dengan kombinasi metode konvensional, yaitu dengan obat-obatan, maupun tradisional secara holistik (menyeluruh). Hal yang sama juga dapat dilakukan pada penderita Penyakit Paru Obstruktif Kronik (PPOK). Teknik latihan pernapasan dan relaksasi diri dapat dilaksanakan sebagai pelengkap, selain dengan konsumsi obat-obatan. Yoga pranayama yang dikombinasikan dengan terapi musik adalah sebuah kombinasi terapi rehabilitasi baru yang dapat dilaksanakan. Studi berikut adalah studi literatur naratif dari sejumlah artikel penelitian dan kajian berbahasa Inggris yang bertujuan untuk mengetahui potensi kombinasi yoga pranayama dan terapi musik sebagai terapi rehabilitasi holistik pada penderita PPOK. Kombinasi terapi tersebut telah terbukti mampu oleh sejumlah literatur dalam menurunkan sesak napas, meningkatkan kapasitas paru-paru dan saturasi oksigen, memperbaiki kebugaran serta meminimalisir tingkat cemas; akan tetapi, belum terdapat penelitian yang memastikan potensi kombinasi terapi tersebut pada pasien PPOK, sehingga penelitian lebih lanjut perlu dilakukan.
\end{abstract}

Kata kunci: Yoga pranayama, terapi musik, rehabilitasi, holistik 


\section{Introduction}

Chronic Obstructive Pulmonary Disease (COPD) is aroused as one of the public health problems all around the world. COPD is a progressive inflammatory disease that effects lungs, characterized by chronic bronchitis, respiratory passage obstruction and emphysema. ${ }^{1}$ COPD patients commonly undergo persistent respiratory distress, including dyspnea (breathless) or chronic cough. This disease stood in the fourth rank of the highest mortality rate diseases and was predicted to get through the third rank in 2020. Almost $6 \%$ of total death globally-around three millions-in 2012, was caused by COPD. ${ }^{2}$ The prevalence of COPD in Indonesia according to Basic Health Research (RISKESDAS or Riset Kesehatan Dasar) 2013 was 3.7\% and slightly increased to 8.6\% based on Indonesia Health Profile year 2017. Those numbers rose along with age. ${ }^{3}$ The disease exacerbation took much of health costs and most of all, disturbed patients' quality of life. ${ }^{3}$

Efforts in avoiding risk factors and applying pharmacological therapy, such as bronchodilators, anti-inflammatory, and inhaled steroids reduce the symptoms of COPD and the frequency of exacerbations. Hence, pharmacological therapy was still unable to overcome the continuing decline in lung function or improve the patients' quality of life. ${ }^{2}$ Therefore, pulmonary rehabilitation was considered as the most effective therapy in achieving those objectives. Based on some studies, rehabilitation also decreases the duration of hospitalization in patients who experience exacerbations. ${ }^{2,4}$ Lung rehabilitation consists of education, breathing exercises, and behavior modification. ${ }^{5}$

Pranayama yoga or "the breathing yoga" is one component of pulmonary rehabilitation training, which has been shown to be able to retrieve the coordination of mind and body. ${ }^{6}$ Several studies have revealed that Pranayama yoga is capable of decreasing the shortness of breath (dyspnea) intensity, improving body oxygenation, as well as easy to do and can be tolerated by people with COPD. ${ }^{6}$ However, there was still no evidence that pranayama yoga can decrease the level of anxiety in COPD patients. ${ }^{6,7}$ The effectiveness of music therapy-especially a slow-tempo instrumental music-as a complementary therapy in patients with COPD has also been proven in a number of studies, besides Pranayama yoga. ${ }^{8}$ It can induce a stress-killing effect and manipulate respiratory control in COPD patients. Music therapy as a non-invasive intervention is also fairly simple to be undergone and tolerated by the patients, so it can be routinely done ${ }^{9,10 .}$ However, in contrast to Pranayama yoga, music therapy could not give adequate evidence in decreasing the intensity of dyspnea.

Based on those reviews of the effectiveness of Pranayama yoga and music therapy in improving COPD patients' quality of life and their potential to be applied practically, then it would be interesting to discuss the potential in combining those therapies. Although each of those two 
therapies had been proven effective as a single therapy in their own way, nevertheless through the combination, it should be recovering and enhancing almost all aspects of COPD patients' quality of life. The study aims to determine the potential of a combination of yoga pranayama and music therapy as a holistic rehabilitation therapy in patients with COPD.

\section{Method}

This study was a narrative literature review. We searched PubMed, Web of Science, the Cochrane Library, and Google Scholar for relevant articles. The selected full-text articles were published in English between 2007-2018; 1 national report was published in Indonesian. The keywords included "pranayama yoga", "music therapy" combined with "COPD," or "chronic obstructive pulmonary disease," combined with "rehabilitation," and "therapy,". Most of the articles chosen were randomized controlled trials, systematic review articles and prospective studies. We found no case reports or case series in the literature review. Additionally, the reference lists of existing reviews and identified articles were reviewed individually to supplement the electronic search. A total of 35 studies were included and most of them were mostly from India.

\section{Results}

Chronic Obstructive Pulmonary Disease Characteristics. Chronic obstructive pulmonary disease (COPD) is a respiratory disease that causes air transportation disturbance to the lungs, resulting in shortness of breath (dyspnea) and feeling tired. ${ }^{1}$ COPD is characterized by chronic bronchitis, emphysema, or a combination of them. Chronic bronchitis (inflammation of the bronchi) is the presence of swelling and mucus or phlegm production in the respiratory tract, whereas emphysema is a condition characterized by damage in the alveoli, so it loses its elasticity in accommodating air. ${ }^{11}$ Smoking is a major cause of COPD in the community and nearly $50 \%$ of all active smokers in the world suffer from COPD. ${ }^{1}$ In addition, indoor or outdoor air pollution, exposure to volcanic dust and other chemicals materials in a long period of time are also risk factors of COPD. ${ }^{11}$ Environmental and genetic factors are also considered to contribute on the emergence of the disease..$^{2,11}$

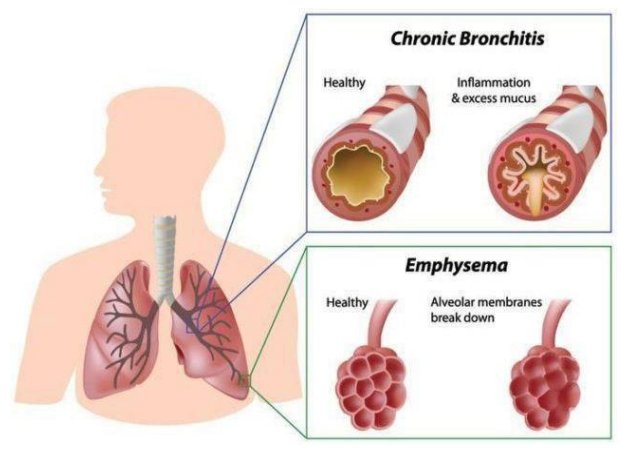

Figure 1. Chronic bronchitis and emphysema manifestation in COPD patients. ${ }^{11}$ 
COPD mainly affects the small respiratory tract and alveoli. An important mechanism in the pathogenesis of COPD is the presence of chronic inflammation and imbalance between oxidants and antioxidants causing oxidative stress. ${ }^{1}$ Oxidative stress contributes to the respiratory passage obstruction and hyperinflation. Inflammatory cells involved in COPD generally white blood cells, with components in the form of neutrophils, macrophages, and lymphocytes. ${ }^{10,11}$ Neutrophils produce chemical substance attractants (chemo-attractants) and proteolytic enzymes that destroy lung tissue so that it is pre-lung lose its elasticity. Neutrophils also increase the activation of macrophages and epithelial cells in producing mucus which is a major sign of COPD. ${ }^{11}$ Macrophages produce cytokines such as $\mathrm{IL}-8, \mathrm{IL}-6, \mathrm{IL}-10, \mathrm{TNF} \alpha$, and reactive oxygen species (ROS) which attract various inflammatory cells and exacerbate inflammation in the lungs. ${ }^{4}$ Lymphocytes CD8+ produces destructive enzymes such as perforin and granzyme B which is able to cause damage to the alveoli epithelial wall. Whereas CD4 lymphocytes induce an autoimmune response in lung tissue. ${ }^{1,11}$

Physiological changes in people with COPD are typically presented in their quality of life. Damage to the elasticity of lung tissue results in a significant narrowing of the airway. It may cause air build-up or pulmonary hyperinflation. ${ }^{11}$ Hyperinflation is a major cause of shortness of breath and poor COPD prognosis. ${ }^{10}$ Formation of connective tissue (fibrosis) in the respiratory tract also causes narrowing which cannot take back to a normal state, even though assisted by bronchodilator drugs. ${ }^{1}$

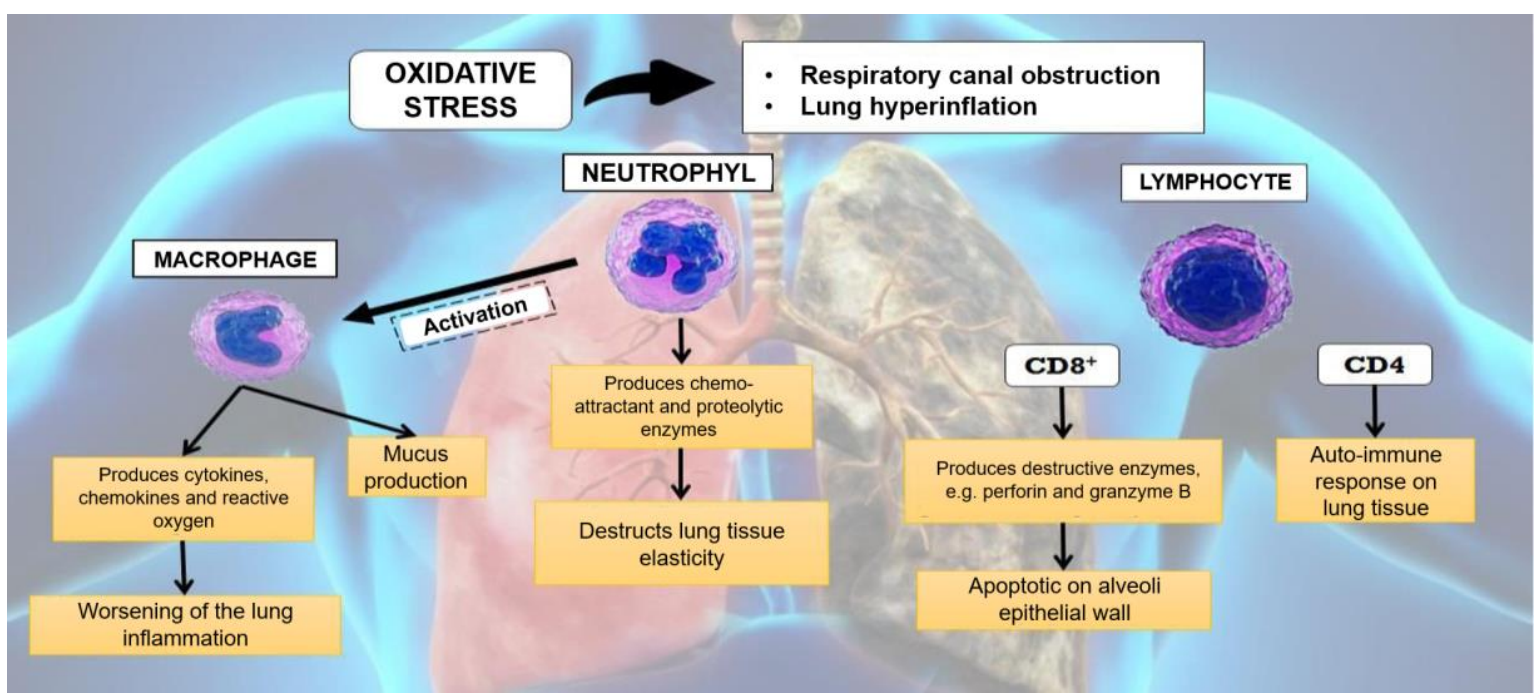

Figure 2. COPD pathophysiology related to oxidative stress and inflammation process.$^{1,10,11}$

Pranayama Yoga Technique. Pranayama is one of the main aspects of yoga. The word pranayama consists of two words derived from Sanskrit, namely the word "prana" and "ayama". The word prana can be interpreted as breathing, breathing of life, vitality, energy, or soul, while the word ayama means to control. So literally, pranayama means control of vital energy, especially 
breathing. ${ }^{12}$ There are more than 100 yoga techniques pranayama mentioned in various Sanskrit writings, which has been classified based on various criteria. Based on technique the basis of breathing used, pranayama can be divided into Dirgha Pranayama (deep and slow regular breathing techniques), Sukha Pranayama (practical breathing techniques to create a steady breathing rhythm), Sukha Purvaka Pranayama, and Vyaghrah Pranayama (tiger breathing technique). ${ }^{16}$ Some main things that must be considered before doing any type of pranayama, which is ensuring that the doer is in a comfortable position, relax, upright body, and minimal distraction. Pranayama then can be begun by breathing in through the nose, holding the breath, and exhaling through the mouth periodically. The breathing cycle is done softly, hence the air can occupy and exit lungs' space as much as possible. ${ }^{12,13}$

Pranayama can be done anywhere and with various kinds of positions. Some commonly used include the position of padmasana and siddhasana (perfect posture). ${ }^{13}$ Padmasana is done by sitting cross-legged. The right leg is placed on top of the left thigh, and vice versa. The right hand is placed on the right knee, while the left hand is on the left knee, with both palms facing up and the middle finger touching the mother finger (Chinmudra). The position of siddhasana or perfect state is done with placing the left heel on the anus, and the right heel on the base of the genital organs. The legs are positioned so that the knee joint can shut perfectly. The hand can be positioned as in padmasana posture. Further illustrations can be observed in Figure $3 .^{12}$
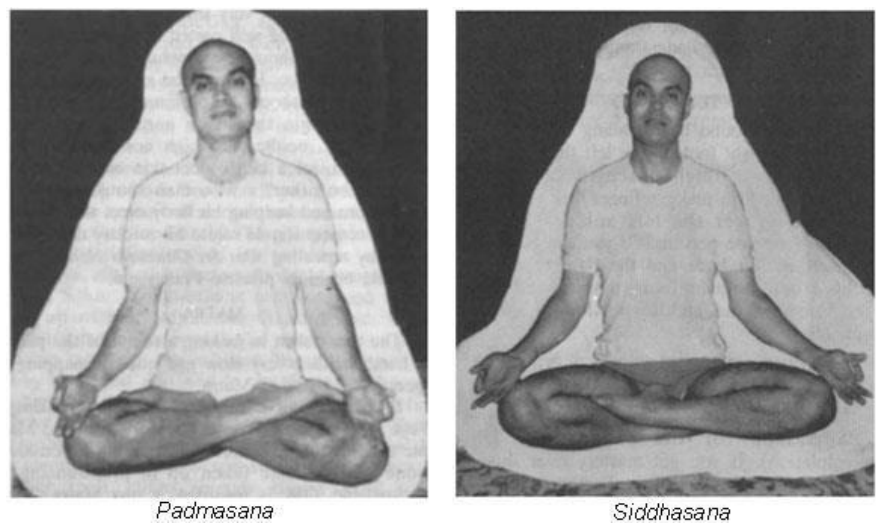

Figure 3. Padmasana and Siddhasana sitting position applied in Pranayama Yoga. ${ }^{12}$

The Clinical Effects of Yoga Pranayama on COPD Patients. A study by Ranjita et al. (2016) evaluated the clinical effects of 12 weeks of integrated yoga pranayama therapy on the likelihood of dyspnea, fatigue, functional activity capacity, oxygen saturation ( $\mathrm{SpO} 2)$, and pulse rate in miners with COPD. There were no side effects found. ${ }^{7}$ Participants who did yoga and those who did not (control group), were statistically the same in various parameters at baseline before being given intervention ( $p>0.05$ ). The results showed a significant reduction in the tendency for dyspnea and fatigue, as well as an increase in functional performance in miners with COPD after the yoga 
intervention. Progressive and significant improvements in key variables in this study, such as functional activity capacity, $\mathrm{SpO} 2$ and pulse rate in the yoga group, but not the control group, indicate the effectiveness of yoga pranayama. ${ }^{7}$

The mechanisms that explain the effects of yoga practice on improving quality of life in COPD patients are complex and interrelated. Yoga generates wellness and synergy in the mind and body. Yoga that is practiced includes breathing control (pranayama), energy control, meditation and relaxation, as well as internal mental focus on self-awareness. Exercises that are carried out regularly are able to improve the overall body system, calm the mind, improve blood circulation, develop lung capacity, and increase the strength of the respiratory muscles. ${ }^{14,15}$ Breathing that is carried out gently and regularly through a combination of abdominal muscles, shoulders and chest, able to help the patient breathe more deeply, which results in improvements to parasympathetic nerve modulation and chemoreceptor sensitivity. ${ }^{7}$

The promising clinical effect of yoga on COPD patients is further strengthened by the results of research in previous studies. In the study of Ranjita et al. Again, the results showed that the sixminute's walk distance (6MWD) increased to 59.45 meters in the yoga group, while the control group was only 16.41 meters. A recent study conducted by Kaminsky et al. in 2017 it was also stated that there was an average increase of 43 meters (doubling) for 6MWD in COPD patients who did pranayama for 12 weeks compared to the control group (baseline). ${ }^{6}$ The increase in 6MWD could be due to yoga as well affect the musculoskeletal and cardiorespiratory systems, through increased cardiovascular efficiency and body homeostatic control. Yoga helps improve physical performance, and increases range of motion in COPD patients through improved skeletal muscle strength, flexibility, endurance, coordination, and static and dynamic stability. ${ }^{16}$

The decrease in the tendency of dyspnea to occur due to decreased reactivity of the sympathetic nerves in prayanama yoga practitioners. This is based on the presence of bronchial dilation which improves the abnormal breathing pattern and reduces the tension of the inspiratory and expiratory muscles. ${ }^{14,15}$ The improvement of the breathing pattern is able to expand the bronchioles, so that the perfusion of the alveoli becomes wider and efficient. Pranayama practice trains lung tissue flexibility, relieves dyspnea by decreasing dynamic hyperinflation, increases the endurance and strength of the respiratory muscles, and optimizes the thoracoabdominal (cheststomach) movement pattern. Modifications to efferent vagal nerve activity also affect the airway canal to reduce dyspnea. ${ }^{17}$

Yoga relaxation techniques, particularly pranayama, have been shown to increase cardiopulmonary endurance through body and breath control, which manifests clinically as increased lung air capacity, increased oxygen delivery to tissues, tolerance to hypoxia due to changes in better chemoreflex, and decreased dyspnea. ${ }^{6}$ It can be observed that there was an 
improvement in blood oxygen saturation (SpO2\%). Peripheral capillary oxygen saturation increased $1.32 \%$ ( $\mathrm{p}<0.001$ ) in the yoga group, whereas there was no change in the control group. ${ }^{7}$

The participants' pulse rate in the yoga group also decreased by $4.28 \%$ ( $\mathrm{p}<0.001$ ), while in the control group the opposite occurred, namely an increase of $1.05 \%(\mathrm{p}=0.054)$. Deep relaxation technique as a component in yoga, especially pranayama, was able to produce this condition through modulation of cardiac autonomic nerve function and efficiency of cardiorespiratory. Pranayama modifies various pulmonary reflexes and intervenes with elements of the central nervous system to improve homeostatic control. This breathing technique can significantly increase baroreceptor sensitivity (BRS) in COPD patients. ${ }^{18}$

Music Therapy and Its Mechanism in Regulating Body System. Humans from various cultural backgrounds have used music since many centuries ago, as a natural instrument to manipulate body movements and their feelings. ${ }^{19}$ Along with the development of science and technology, people with various age groups use more energy and peace produced by music to regulate their daily energy levels, namely for physical exercise as well as relaxation. Music consists of several elements, including tempo (speed), rhythm, timbre (sound quality), dynamics (loudness), harmony, melody (tone), and sometimes also the lyrics. Rhythm in music is very influential because it is able to mimic the body's internal rhythm, so it is easily recognized and responded to by the brain. ${ }^{20}$ Neurophysiological responses are stimulated by complex interactions involving all elements of music that have a strong influence on mood and emotional experience. ${ }^{21}$ Many people take advantage of the body's response to music, because its effect in modifying the level of arousal and optimizing physical functions such as walking and other movement patterns.

When choosing the type of music to be heard or played, we can choose music that is in sync with the current state of feeling or energy level, or can choose music to change mood itself. ${ }^{22}$ For example if someone feels sad, they might choose the type of stimulating music which has fast tempo (>120 beats per minute), with a rhythm and a melody varies to provide additional energy. The same goes for those who want to get exercise or want to create an atmosphere of enthusiasm. Conversely, if they want a calm condition, they may choose the type of relaxational music, with slow tempo ( $<80$ beats per minute) and consistent rhythm, to help relieve tension and stress. ${ }^{23,24}$

Music Therapy in Pain, Anxiety and Stress Management. Musical experience can cause the neuroendocrine system or hormonal to release hormones such as dopamine and serotonin, which can create feelings of pleasure. ${ }^{21}$ Listening to music can reduce levels anxiety (known as the anxiolytic effect), by suppressing system activity sympathetic nerves, thereby reducing various physiological stress markers, such as the hormones cortisol and adrenaline. ${ }^{25}$ A number of studies state that music also able to activate the limbic system, releasing endorphins which can make us feel better and reduce pain perception. ${ }^{26}$ Music plays a role distractive stimulants capable of producing physiological responses to fight pain, one of which is the endorphin hormone. Music can 
also reduce the pain threshold by reducing stress. ${ }^{27}$ Therefore, music therapy used as a complementary therapy in preventive efforts and rehabilitative in various sufferers of acute to chronic diseases. Therapy music consists of two types of intervention choices, namely active and passive music therapy. Active music therapy involves the patient directly in the process of producing music, including vocal training (singing), or playing instrumental music, whereas in passive music therapy, patients only listen to the music produced. Music therapy is nonpharmacological and non-invasion so that it does not cause side effects in its implementation. ${ }^{24}$

The Clinical Effects of Music Therapy on Patients with COPD. Several studies have shown that music therapy has a positive effect on COPD patients, including increasing control of the breathing rate, reducing hyperinflation, reducing dyspnea and improving the patients' quality of life.$^{28}$ One of the music therapies commonly used is listening to music, which can relieves dyspnea when a person is physically active. A study showed that listening to music can provide a distractive stimulus which can increase the perceptual threshold for dyspnea-genic stimuli (dyspneagenic desensitization) so that the dyspneagenic stimulus cannot reach the conscious phase. Increasing the ratio of non-dyspnea-genic distracted stimuli to dyspneagenic stimuli can alter one's perception of dyspnea (Figure 3). This distractive stimulus can increase a person's intensity in physical activity and improve the quality of life for people with COPD. ${ }^{29,30}$ Studies conducted by Singh et al. (2009) showed that COPD patients who listened to music experienced a significant reduction in dyspnea and anxiety levels, using the visual analogue dyspnea scale (VADS), the dyspnea rate decreased from $49.06+17.1$ to $23.91+10.2$ (p <0.01). ${ }^{8}$

Another study showed that listening to music can reduce anxiety and depression that often occurs in patients with advanced COPD with a prevalence of around 7-80\% and 2-80\%, respectively. ${ }^{31,32}$ This was proven in a study which showed a decrease in the number of anxiety from 17.14 to 12.86 . In addition, pain also decreased by about $25 \%$, from a score of 5.43 to 4 , after being intervened with music therapy in the form of listening to music. ${ }^{32}$ That fact was because music had a relaxing effect which can trigger the production of endorphins to reduce pain and provide a sense of comfort for the listeners. ${ }^{8}$ 
Table 1. Studies Describing Pranayama Yoga or Music Therapy Intervention in COPD Patients

\begin{tabular}{|c|c|c|c|c|c|c|c|c|}
\hline & $\begin{array}{c}\text { Kaminsky et } \\
\text { al. }^{6}\end{array}$ & Ranjita et al. $^{7}$ & Soni et al. ${ }^{15}$ & $\begin{array}{c}\text { Mohammed et } \\
\text { al. }^{16}\end{array}$ & $\begin{array}{c}\text { Panigrahi et } \\
\text { al. }^{8}\end{array}$ & Lee et al. ${ }^{29}$ & Singh et al. ${ }^{30}$ & $\begin{array}{c}\text { Krishnaswamy } \\
\text { and Nair. }{ }^{32}\end{array}$ \\
\hline Publication date & $\begin{array}{c}\text { 1 September } \\
2017\end{array}$ & $\begin{array}{l}18 \text { August } \\
2016\end{array}$ & July 2015 & $\begin{array}{c}15 \text { December } \\
2016\end{array}$ & January 2014 & $\begin{array}{c}\text { August } \\
2015\end{array}$ & $\begin{array}{c}\text { 1 November } \\
2009\end{array}$ & July 2016 \\
\hline Design of study & $\begin{array}{l}\text { Randomized } \\
\text { controlled } \\
\text { trial (double- } \\
\text { blind) }\end{array}$ & $\begin{array}{l}\text { Randomized } \\
\text { controlled trial } \\
\text { (single-blind) }\end{array}$ & $\begin{array}{l}\text { Randomized } \\
\text { controlled trial } \\
\text { (single-blind) }\end{array}$ & $\begin{array}{l}\text { Systematic } \\
\text { review }\end{array}$ & $\begin{array}{l}\text { Systematic } \\
\text { review }\end{array}$ & $\begin{array}{l}\text { Systematic } \\
\text { review }\end{array}$ & $\begin{array}{c}\text { Randomized } \\
\text { controlled } \\
\text { trial }\end{array}$ & $\begin{array}{c}\text { Comparative } \\
\text { study }\end{array}$ \\
\hline Country & US & India & India & N/A & N/A & N/A & India & India \\
\hline Study objectives & $\begin{array}{l}\text { Determine } \\
\text { whether } \\
\text { pulmonary } \\
\text { rehabilitation } \\
\text { improves } \\
\text { exercise } \\
\text { tolerance in } \\
\text { COPD } \\
\text { patients }\end{array}$ & $\begin{array}{l}\text { Evaluate the } \\
\text { effectiveness } \\
\text { of IAYT in the } \\
\text { management } \\
\text { of dyspnea and } \\
\text { fatigue in coal } \\
\text { miners with } \\
\text { COPD }\end{array}$ & $\begin{array}{l}\text { Determine } \\
\text { effects of yoga } \\
\text { exercises in } \\
\text { COPD patients } \\
\text { by measuring } \\
\text { pulmonary } \\
\text { function tests } \\
\text { along with } \\
\text { diffusion } \\
\text { capacity }\end{array}$ & $\begin{array}{l}\text { Describe effect } \\
\text { of controlled } \\
\text { breathing } \\
\text { techniques, } \\
\text { and/or oxygen } \\
\text { supplementation } \\
\text { techniques on } \\
\text { autonomic } \\
\text { function COPD } \\
\text { patients }\end{array}$ & $\begin{array}{l}\text { Examine the } \\
\text { impact of music } \\
\text { on } \\
\text { psychological } \\
\text { and } \\
\text { physiological } \\
\text { outcomes } \\
\text { among } \\
\text { individuals with } \\
\text { COPD }\end{array}$ & $\begin{array}{l}\text { Establish } \\
\text { the effect of } \\
\text { DAS on } \\
\text { exercise } \\
\text { capacity, } \\
\text { symptoms, } \\
\text { and health- } \\
\text { related } \\
\text { quality of } \\
\text { life }\end{array}$ & $\begin{array}{l}\text { Evaluate the } \\
\text { acute effects } \\
\text { of music and } \\
\text { PMR in } \\
\text { hospitalized } \\
\text { COPD } \\
\text { subjects after } \\
\text { exacerbation }\end{array}$ & $\begin{array}{c}\text { Assess the } \\
\text { effect of music } \\
\text { therapy on pain } \\
\text { scores and } \\
\text { anxiety levels of } \\
\text { cancer patients } \\
\text { with pain }\end{array}$ \\
\hline \multicolumn{9}{|l|}{$\begin{array}{l}\text { Characteristics } \\
\text { of subjects }\end{array}$} \\
\hline Number & 43 & 81 & 60 & & $7-72$ & 415 & 72 & N/A \\
\hline Age & $>18$ years & $36-60$ years & $30-60$ years & N/A & $>18$ years & N/A & N/A & N/A \\
\hline $\begin{array}{l}\text { Other } \\
\text { criteria(s) }\end{array}$ & $\begin{array}{l}\text { Symptomatic, } \\
\text { moderate-to- } \\
\text { severe COPD }\end{array}$ & $\begin{array}{l}\text { Stable stages II } \\
\text { and III COPD }\end{array}$ & $\begin{array}{l}\text { Stable mild-to- } \\
\text { moderate } \\
\text { COPD }\end{array}$ & & $\begin{array}{l}\text { COPD patients } \\
\text { only }\end{array}$ & N/A & $\begin{array}{c}\text { Acute } \\
\text { exacerbation }\end{array}$ & $\begin{array}{c}\text { Cancer patients } \\
\text { admitted for } \\
\text { pain relief }\end{array}$ \\
\hline Main finding(s) & $\begin{array}{l}\text { The 6MWD } \\
\text { increased in } \\
\text { the } \\
\text { pranayama } \\
\text { group; } \\
\text { Pranayama } \\
\text { improved } \\
\text { inspiratory } \\
\text { capacity and } \\
\text { air trapping }\end{array}$ & $\begin{array}{l}\text { Statistically } \\
\text { significant } \\
\text { reductions in } \\
\text { dyspnea, } \\
\text { fatigue, pulse } \\
\text { rate, SpO2\% } \\
\text { and } 6 \text { min } \\
\text { walk distance } \\
\text { (p < } 0.001 \\
\text { each) within } \\
\text { yoga group }\end{array}$ & $\begin{array}{l}\text { Significant } \\
\text { improvement in } \\
\text { transfer factor } \\
\text { of lung for } \\
\text { carbon } \\
\text { monoxide of } \\
\text { the yoga group } \\
(\mathrm{p}<0.001)\end{array}$ & $\begin{array}{l}\text { Moderato- } \\
\text { strong evidence } \\
\text { supported } \\
\text { oxygen } \\
\text { supplementation } \\
\text { and slow } \\
\text { breathing } \\
\text { techniques } \\
\text { enhancing the } \\
\text { baroreceptor } \\
\text { sensitivity }\end{array}$ & $\begin{array}{l}\text { Music showed } \\
\text { improvement in } \\
\text { the } \\
\text { psychological } \\
\text { outcomes } \\
\text { (dyspnea, } \\
\text { anxiety) and } \\
\text { mixed results of } \\
\text { physiological } \\
\text { outcomes } \\
\text { (breathing } \\
\text { control) }\end{array}$ & $\begin{array}{c}\text { DAS } \\
\text { increased } \\
\text { exercise } \\
\text { capacity } \\
\text { when } \\
\text { applied } \geq 2 \\
\text { months of } \\
\text { exercise } \\
\text { training } \\
\text { (WMD, 98 } \\
\text { m; } 95 \% \mathrm{CI}, \\
47-150 \mathrm{~m} \text { ) }\end{array}$ & $\begin{array}{l}\text { Statistically } \\
\text { significant } \\
\text { main effect } \\
\text { across the } \\
\text { sessions for } \\
\text { state anxiety, } \\
\text { trait anxiety, } \\
\text { dyspnea, PR } \\
\text { and RR (p < } \\
0.001 \text { each) }\end{array}$ & $\begin{array}{l}\text { Statistically } \\
\text { significant } \\
\text { reduction in } \\
\text { pain scores of } \\
\text { the test group } \\
\text { after music } \\
\text { therapy ( } \mathrm{p}= \\
0.003 \text { ). The } \\
\text { reduction in } \\
\text { anxiety levels } \\
\text { was not } \\
\text { significant }\end{array}$ \\
\hline Conclusion & $\begin{array}{l}\text { Pranayama } \\
\text { was } \\
\text { associated } \\
\text { with } \\
\text { improved } \\
\text { exercise } \\
\text { tolerance in } \\
\text { patients with } \\
\text { COPD }\end{array}$ & $\begin{array}{l}\text { IAYT benefits } \\
\text { coal miners } \\
\text { with COPD } \\
\text { and can be } \\
\text { seen as adjunct } \\
\text { to } \\
\text { conventional } \\
\text { therapy for } \\
\text { pulmonary } \\
\text { rehabilitation }\end{array}$ & $\begin{array}{l}\text { Yoga breathing } \\
\text { exercises } \\
\text { improve } \\
\text { diffusion } \\
\text { capacity and } \\
\text { beneficial to } \\
\text { COPD patients } \\
\text { as an adjunct } \\
\text { therapy }\end{array}$ & $\begin{array}{c}\text { Oxygen } \\
\text { supplementation } \\
\text { and controlled } \\
\text { breathing } \\
\text { techniques have } \\
\text { profound } \\
\text { positive } \\
\text { influence in } \\
\text { patients with } \\
\text { COPD }\end{array}$ & $\begin{array}{l}\text { Music showed } \\
\text { positive result } \\
\text { on } \\
\text { psychological } \\
\text { outcomes but } \\
\text { mixed result on } \\
\text { physiological } \\
\text { outcomes }\end{array}$ & $\begin{array}{l}\text { DAS } \\
\text { appears to } \\
\text { reduce } \\
\text { symptoms } \\
\text { of dyspnea } \\
\text { and fatigue } \\
\text { during } \\
\text { exercise; at } \\
\text { rest are } \\
\text { inconsistent }\end{array}$ & $\begin{array}{l}\text { Music and } \\
\text { PMR are } \\
\text { effective in } \\
\text { reducing } \\
\text { anxiety, } \\
\text { dyspnea and } \\
\text { physiologic } \\
\text { measures in } \\
\text { COPD } \\
\text { patients }\end{array}$ & $\begin{array}{l}\text { Music therapy } \\
\text { was found to } \\
\text { lower the pain } \\
\text { score of a } \\
\text { patient who had } \\
\text { received } \\
\text { standard } \\
\text { palliative care } \\
\text { for pain } \\
\text { reduction }\end{array}$ \\
\hline Recommendation & $\begin{array}{l}\text { Needs to be } \\
\text { confirmed in } \\
\text { future, larger } \\
\text { clinical trial }\end{array}$ & $\begin{array}{l}\text { Larger scale } \\
\text { research with } \\
\text { longer follow- } \\
\text { up should be } \\
\text { conducted }\end{array}$ & N/A & $\begin{array}{l}\text { Focus on } \\
\text { specific long- } \\
\text { term effects of } \\
\text { these techniques } \\
\text { on patients' } \\
\text { condition }\end{array}$ & $\begin{array}{l}\text { More research } \\
\text { of a longer } \\
\text { duration and } \\
\text { with a larger } \\
\text { sample size is } \\
\text { needed }\end{array}$ & N/A & N/A & $\begin{array}{l}\text { A study with a } \\
\text { larger sample } \\
\text { size should be } \\
\text { undertaken to } \\
\text { conclude the } \\
\text { fact }\end{array}$ \\
\hline
\end{tabular}




\section{Discussion}

The Potential of Yoga Pranayama and Music Therapy Combination as a Holistic Rehabilitation Therapy in COPD Patients. Each of pranayama yoga and music therapy alone has its own role in improving COPD patients' health condition. Pranayama yoga could help COPD patients to breathe more deeply thereby reducing the incidence of dyspnea, as well as increasing lung capacity and oxygen saturation. Pranayama yoga also improves fitness and energy control through increased cardiovascular efficiency and control of body homeostasis, however not many studies expressed the impact of pranayama yoga in regulating psychological health of COPD patients. In the other hand, music therapy has the main potential to reduce anxiety as one comorbid of COPD, however this therapy could not improve lung capacity and decrease the incidence of dyspnea as well as the Pranayama yoga, hence a combination should be considered in order to maximize the effectiveness and cover the weakness of each therapy.

A study conducted by Ramesh et al. (2013) in patients following cardiac surgery showed an initial view that a combination of music therapy and yoga pranayama can significantly reduce anxiety and pain levels. The combination therapy intervention for three consecutive days was able to reduce the level of anxiety from a score of 43.15 to 30.5 , or about $30 \% .{ }^{33}$ Anxiety is a symptom that often experiences comorbidity in patients with COPD, so a decrease in anxiety levels can increase quality of life for COPD patients. Apart from feeling anxious, pain is also a relatively uncomfortable condition that can occur in COPD sufferers. In the same study, the intervention of yoga pranayama and music therapy was able to reduce pain levels in postoperative patients (Figure 4). ${ }^{33}$ A study also showed that dyspnea and pain were correlated in the scope of discomfort. So, it can be stated that the decrease in pain is a decrease in the tendency of dyspnea in these patients. ${ }^{34}$

The combination of music and yoga therapies could produce the desired result in reducing the anxiety and enhancing deep breathing thereby facilitating relaxation as stated by a study from Ajmera et al. (2018) in cardiac patients. That study found that respiratory rate and anxiety level in a post-hoc test for music-yoga group compared with music group only were significantly improved in two days from 24 to 20 and 0.94 to 0.29 respectively ( $\mathrm{p}=0.001 ; \mathrm{p}=0.001$ ) ${ }^{35}$ It also stated that the combination therapy complement each other. The pranayama intervention improved the deep breathing pattern which induces relaxation, meanwhile the music therapy maintained that state through helping people focus their attention away from distressing situations and generate positive moods and emotions which finally reduces the anxiety level. Both the reduction of anxiety and the regularization of physiological responses suppressed the sympathetic activity leading to reduce adrenergic activity and regulation of autonomic respiratory rhytms. ${ }^{35}$

Another positive thing from this therapy combination was it can be done anywhere and anytime, in groups or independently, without supervision. Briefing from an instructor is only needed the first time to introduce the basic technique. The period of implementing this combination 
therapy can be adjusted according to needs, such as once a week, once every three days, or every day. One period of yoga pranayama and music therapy can be carried out for 15-20 minutes, with the proportion of the first 5 minutes specifically for listening to instrumental music only, and the next 10-15 minutes for doing yoga pranayama at the same time while listening to instrumental music. ${ }^{33}$ The music chosen is a type of instrumental music without lyrics with a slow to medium tempo (60-80 beats per minute). This type of music was chosen because it can have a distractive and calming effect (relaxation). ${ }^{8}$ Yoga pranayama is carried out with an upright, relaxed body and a calm environment, as well as instrumental music heard at the same time in a relaxed state and with closed eyes, to focus concentration. ${ }^{8,19}$ This therapy also has no side effects, so it can be carried out continuously, both by the patients and healthy people. ${ }^{7}$

\section{Conclusion}

Yoga pranayama and music therapy are beneficial to reduce physiological disturbances in COPD patients, nonetheless those therapy alone could improve only limited aspects of patients' quality of life. The combination of yoga pranayama and music therapy was introduced in order to maximize each impact and enhance the result of the stand-alone therapy. That combination was also relatively simple and easy to do, therefore it has the potential to be an effective holistic rehabilitation therapy for COPD patients. However, further research on the effectiveness of the combination of yoga pranayama and music therapy as a holistic rehabilitation therapy in COPD patients is needed on a larger scale. A review of the possible side effects is also required, so that later information regarding the technique for implementing this combination therapy can be disseminated and can be implemented by the community.

\section{Acknowledgment}

We would like to thank Komang Ayu Kartika Sari, M.D., MPH. (Department of Community and Preventive Medicine) for her valuable contribution on giving suggestion and recommendation regarding to this study.

\section{Funding}

This study received no financial support.

\section{Conflict of Interest}

The authors declare that they have no conflict of interest related to the study. 


\section{Reference}

1. Brashier BB, Kodgule R. Risk factors and pathophysiology of chronic obstructive pulmonary disease (COPD). J Assoc Physicians India. 2012;60 Suppl(February):17-21.

2. Högman M, Sulku J, Ställberg B, Janson C, Bröms K, Hedenström H, et al. 2017 global initiative for chronic obstructive lung disease reclassifies half of COPD subjects to lower risk group. Int J COPD. 2018;13:165-73.

3. Badan Penelitian dan Pengembangan Kemenkes RI. Riset Kesehatan Dasar. 2013;

4. Soeroto AY, Sryadinata H. Penyakit Paru Obstruktif Kronik (PPOK). Indones J Chest Crit Care Med. 2014;1(2):84-8.

5. Spruit MA, Singh SJ, Garvey C, Zu Wallack R, Nici L, Rochester C, et al. An official American thoracic society/European respiratory society statement: Key concepts and advances in pulmonary rehabilitation. Am J Respir Crit Care Med. 2013;188(8).

6. Kaminsky DA, Guntupalli KK, Lippmann J, Burns SM, Brock MA, Skelly J, et al. Effect of Yoga Breathing (Pranayama) on Exercise Tolerance in Patients with Chronic Obstructive Pulmonary Disease: A Randomized, Controlled Trial. J Altern Complement Med. 2017;00(00):acm.2017.0102.

7. Ranjita R, Hankey A, Nagendra HR, Mohanty S. Yoga-based pulmonary rehabilitation for the management of dyspnea in coal miners with chronic obstructive pulmonary disease: A randomized controlled trial. J Ayurveda Integr Med. 2016;7(3):158-66.

8. Panigrahi A, Sohani S, Amadi C, Joshi A. Role of music in the management of chronic obstructive pulmonary disease (COPD): A literature review. Technol Heal Care. 2014;22(1):53-61.

9. Vijayan VK. Chronic obstructive pulmonary disease. Vol. 137, Indian Journal of Medical Research. 2013. p. 251-69.

10. Fletcher CM, Pride NB. Definitions of emphysema, chronic bronchitis, asthma, and airflow obstruction: 25 years on from the Ciba symposium. Thorax. 1984 Feb;39(2):81-5.

11. Bourdin A, Burgel PR, Chanez P, Garcia G, Perez T, Roche N. Recent advances in COPD: Pathophysiology, respiratory physiology and clinical aspects, including comorbidities. Vol. 18, European Respiratory Review. 2009. p. 198-212.

12. International Yogalayam. Yoga breathing techniques [Internet]. 2007 [cited 2020 Aug 27]. p. 1-5. Available from: https://www.yumpu.com/en/document/view/29579844/yogabreathing-techniques-international-yogalayam

13. Sivananda SS. The Science of Pranayama. Science. 2000. 1-73 p.

14. Katiyar SK, Bihari S. Role of Pranayama in Rehabilitation of COPD patients -a Randomized Controlled Study. Indian J Allergy Asthma Immunol. 2006;20(2):98-104. 
15. Soni R, Munish K, Singh K, Singh S. Study of the effect of yoga training on diffusion capacity in chronic obstructive pulmonary disease patients: A controlled trial. Int J Yoga. 2012;5(2):123-7.

16. Mohammed J, Da Silva H, Van Oosterwijck J, Calders P. Effect of respiratory rehabilitation techniques on the autonomic function in patients with chronic obstructive pulmonary disease: A systematic review. Vol. 14, Chronic Respiratory Disease. 2017. p. 217-30.

17. Lord VM, Cave P, Hume VJ, Flude EJ, Evans A, Kelly JL, et al. Singing teaching as a therapy for chronic respiratory disease - a randomised controlled trial and qualitative evaluation. BMC Pulm Med. 2010;10.

18. Eley R, Gorman D. Didgeridoo playing and singing to support asthma management in aboriginal australians. J Rural Heal. 2010;26(1):100-4.

19. Schneck DJ, Berger DS, Rowland G. The Music Effect: Music Physiology and Clinical Applications. London and Philadelphia: Jessica Kingsley Publishers; 2006. 243 p.

20. DeNora T. Music in Everyday Life [Internet]. Music in Everyday Life. Cambridge University Press; 2000 [cited 2020 Aug 27]. Available from: /core/books/music-ineveryday-life/EE77B0AC56959E4874C2BF5B48A0F7E2

21. Zatorre RJ, Chen JL, Penhune VB. When the brain plays music: Auditory-motor interactions in music perception and production. Nat Rev Neurosci. 2007 Jul;8(7):547-58.

22. Tomaino CM. The Role of Music in the Rehabilitation of Persons with Neurologic Diseases : Gaining Access to ' Lost Memory' and Preserved Function Through Music Therapy. Music Ther Today. 2002;(August):1-5.

23. Bradt J, Dileo C, Potvin N. Music for stress and anxiety reduction in coronary heart disease patients. Cochrane Database Syst Rev. 2013 Dec 28;(12):CD006577.

24. Beaulieu-Boire G, Bourque S, Chagnon F, Chouinard L, Gallo-Payet N, Lesur O. Music and biological stress dampening in mechanically-ventilated patients at the intensive care unit ward-a prospective interventional randomized crossover trial. J Crit Care. 2013 Aug;28(4):442-50.

25. Linnemann A, Kappert MB, Fischer S, Doerr JM, Strahler J, Nater UM. The effects of music listening on pain and stress in the daily life of patients with fibromyalgia syndrome. Front Hum Neurosci. 2015;9:434.

26. Bulfone T, Quattrin R, Zanotti R, Regattin L, Brusaferro S. Effectiveness of music therapy for anxiety reduction in women with breast cancer in chemotherapy treatment. Holist Nurs Pract. 2009;23(4):238-42.

27. Bausewein C, Booth S, Gysels M, Higginson I. Non-pharmacological interventions for breathlessness in advanced stages of malignant and non-malignant diseases. Bausewein C, editor. Cochrane Database of Systematic Reviews. Chichester, UK: John Wiley and Sons 
Ltd; 2008.

28. Ho CF, Maa SH, Shyu YIL, Lai Y Te, Hung TC, Chen HC. Effectiveness of paced walking to music at home for patients with COPD. COPD J Chronic Obstr Pulm Dis. 2012;9(5):447-57.

29. Lee AL, Desveaux L, Goldstein RS, Brooks D. Distractive auditory stimuli in the form of music in individuals with COPD: A systematic review. Vol. 148, Chest. The American College of Chest Physicians; 2015. p. 417-29.

30. Singh VP, Rao V, Prem V, RC S, K KP. Comparison of the effectiveness of music and progressive muscle relaxation for anxiety in COPD--A randomized controlled pilot study. Chron Respir Dis. 2009;6(4):209-16.

31. Norweg A, Collins EG. Evidence for cognitive-behavioral strategies improving dyspnea and related distress in COPD. Vol. 8, International Journal of COPD. 2013. p. 439-51.

32. Krishnaswamy P, Nair S. Effect of music therapy on pain and anxiety levels of cancer patients: A pilot study. Indian J Palliat Care. 2016;22(3):307.

33. Ramesh C, Priya G, Jyothi K, Eilean Victoria L. Effectiveness of twin therapeutic approaches on pain and anxiety among patients following cardiac surgery. Nitte Univ J Heal Sci. 2013;3(4):34-9.

34. Schön D, Dahme B, Leupoldt A Von. Associations between the perception of dyspnea, pain, and negative affect. Psychophysiology. 2008;45(6):1064-7.

35. Ajmera S, Amirtha Ganesh B, Bhavanani A, Dayanidy G, Ezhumalai G. A comparative study on the effect of music therapy alone and a combination of music and yoga therapies on the psychophysiological parameters of cardiac patients posted for angiography. SBV J Basic, Clin Appl Heal Sci. 2018;1(1):13-8. 